\title{
Chapter 7 \\ Who Cares? An Event History Analysis of Co-parenthood Dynamics in Belgium
}

\author{
Elke Claessens and Dimitri Mortelmans
}

\begin{abstract}
Until the end of the twentieth century, child custody arrangements after separation typically continued the gendered pre-separation parenting division, with mothers taking up childcare and fathers paying child support. Recently, there has been a significant rise in co-parenting after separation, reflecting the trend towards more socio-economic, work- and childcare-related gender equality during the relationship. However, it remains unclear to what extent the organization of the pre-separation household dominates over important changes in the lives and labor force participation of parents after separation in choosing to co-parent.

This study uses longitudinal Belgian register data to consider the effect of postseparation dynamics in parents' life course and labor force participation in deciding to co-parent. While certain pre-separation characteristics remain predictive of co-parenting, our results suggest a societal trend towards co-parenting as the parenting norm. Increased time in paid work positively affects co-parenting probabilities, but we find no effect of a post-separation income increase, even though this would imply greater bargaining power to obtain sole custody. As such, the investigated post-separation changes seem to be an indication of parents moving towards supporting and attempting to gain gender equal parenting after separation.
\end{abstract}

Keywords Shared physical custody · Gender equality · Employment · Income · Re-partnering

\subsection{Introduction}

When parents separate, child custody arrangements have been found to continue the parental care-giving roles that were present during the relationship. Until the end of the twentieth century this meant that the societally dominant caring roles were

\footnotetext{
E. Claessens $(\bowtie) \cdot$ D. Mortelmans

Centre for Population, Family and Health (CPFH), University of Antwerp, Antwerp, Belgium e-mail: elke.claessens@uantwerpen.be; dimitri.mortelmans@uantwerpen.be
} 
generally perpetuated in mother-sole custody arrangements. Meanwhile, fathers paid child support to compensate for their unequal share of childcare (DiFonzo 2014; Vanassche et al. 2017). More recently, parents' responsibilities have become less divided. Mothers are now spending more time in the workforce and less time at home caring for children (Bianchi et al. 2012), whereas fathers' active involvement in childcare has extended the father role beyond that of the breadwinner (Meyer et al. 2017; Van Krieken 2005). This increased equality in parental care-giving during the relationship has, in turn, been found to encourage parents to continue to share the care of children after separation (Nielsen 2013a; Trinder 2010). However, in understanding what encourages separating parents to share childcare, research mainly considers characteristics before the separation or at the time of the study (Nielsen 2011, 2013a). This overlooks lifestyle and labor force changes in the turbulent early post-separation years, which may also have an important effect on how parents divide care.

In a recent study on the stability of care arrangements, Poortman and van Gaalen (2017) find that, controlling for the pre-separation situation, post-separation changes in children's needs, father's employment and practical factors can lead parents to stop sharing care within 2 years after separation. Currently, not much is known about the opposite situation, namely what encourages parents to begin sharing care later on. Controlling for important pre-separation characteristics, this chapter investigates the influence of three post-separation dynamics (parents' financial position, labour force participation and re-partnering) on switching to an equally shared physical custody arrangement 2 years after separation. Furthermore, as what facilitates sharing childcare with an ex-partner differs for men and women (Bakker and Mulder 2013; Juby et al. 2005), we also investigate whether post-separation life course and labor force dynamics affect the switch to equally sharing care differently for fathers and mothers. As such, this chapter offers insight both in the largely unexplored role played by post-separation dynamics as in potential gender differences in how parents' post-separation lives affect the division of childcare.

\subsection{Theoretical Framework}

\subsubsection{Sharing Care in Belgium}

"Shared physical custody" is a term used for various custody arrangements where parents either equally or unequally, legally and/or physically share the care of their children after separation. In this chapter, we consider it solely as the situation where children live with each parent for an equal amount of time. While not legally mandatory in Belgium, an equal division of physical custody over a child is the primary custody arrangement to be considered by a judge (Vanassche et al. 2017). Embedded in an increasing recognition of the importance of fatherly care, there has been a fourfold increase in the number of children with an alternating residence since the 1990's. Recently, equally shared physical custody has been estimated to 
represent one fourth of all custody arrangements in Belgium (Mortelmans et al. 2011). Furthermore, children in shared physical custody in Belgium typically spend an (almost) equal amount of time with each parent (e.g. 1 week with the mother, 1 week with the father) (Vanassche et al. 2017).

These considerations make it interesting to study the specific Belgian configuration of fiscal shared physical custody. In this arrangement, parents equally divide the child-related tax benefits, which would otherwise be granted to the parent with whom the child is domiciled. The only requirement is that parents have the child living with them for an equal amount of time, while not paying or receiving child support for that child (FOD Financiën 2018c). Studying fiscal shared physical custody has various advantages. First of all, it exempts us from somewhat arbitrarily deciding the cut-off defining "equally" shared physical custody - a typical challenge in custody research (Bartfeld 2011). Furthermore, the fiscal configuration is open to all separating parents, regardless of their pre-separation union. Therefore, we do not only take into account care agreements of divorcees but also of legally and unregistered cohabitating couples, which are underrepresented groups in custody research (Maldonado 2014). Finally, it is not a restrictive system, in that sense that it does not benefit affluent parents over lower-income groups. As such, while there are specific cases where there are less benefits than when paying tax-deductible child support (e.g. for large families (Gezinsbond 2021)), we can expect minimal selection effects.

\subsubsection{Sharing Care, Perpetuating Equality?}

Equal shared physical custody is often portrayed as the care arrangement with the best outcomes for all parties. While the benefits of this residency arrangement can be (partially) attributed to it being chosen by less conflicted and better cooperating parents (Fehlberg et al. 2011; Trinder 2010), continued contact with both parents after separation - controlled for the quality of the parental relationship - has been found to have a positive effect on children's academic, psychological, emotional, and social well-being (Bauserman 2002; Nielsen 2013b; Westphal 2015). Children who alternate their residence also generally report a better relationship with their father and an equally good relationship with their mother as children who predominantly live with their mother (Sodermans et al. 2013b). Furthermore, sharing childcare has been found to boost the life-satisfaction of parents (Van der Heijden et al. 2015). Compared to being in a traditional sole custody arrangement, fathers with an equal time share as mothers tend to have a better relationship with their child while not having less time for a social life, whereas mothers have more time to engage in leisure activities and experience more freedom to start a new relationship (Bakker and Karsten 2013; Vanassche et al. 2017). As such, while reflecting equal pre-separation parenting roles (Cancian et al. 2014; Juby et al. 2005), shared physical custody also perpetuates and increases equality after separation. 
These benefits can be expected to be more widely applicable with the increasing adoption of shared physical custody as the parenting norm (Nielsen 2014). Nevertheless, in most countries, equally sharing care is not legally mandatory, nor is it the default residency arrangement. An abundance of research therefore looks into which household, parent and child characteristics are predictive of sharing custody after separation. However, most studies - mainly due to data restrictions - consider both these characteristics and choosing to share care as "static", limiting themselves to mapping who has shared physical custody at a certain point in time. We argue that this overlooks the turbulence of the early post-separation years, when shifts in socioeconomic position and variability in custody arrangements are common (Feinberg et al. 2007). For example, it is likely that people who do not initially opt for shared physical custody go through various changes (i.e. in terms of resources) that lead them to switch to sharing care later on, while not having the "expected" pre-separation characteristics to do so (Sodermans et al. 2011). In the following sections, we build on existing shared custody research and consider three areas of post-separation dynamics that could affect switching to an equal shared physical custody arrangement 2 years after separation: the financial position, labour force participation and re-partnering. Furthermore, as men and women have been found to have differing post-separation socio-economic trajectories (de Regt et al. 2012; Thielemans and Mortelmans 2019), we also consider whether these dynamics affect the switch to shared care differently for fathers than for mothers.

\subsubsection{Labor Force Participation}

As mentioned above, equality in caregiving is as much a predictor as it is an outcome of having shared physical custody after separation. During the relationship, this mainly has to do with available time and is therefore strongly connected to the labor force participation of mothers. If a mother spends more time in paid work, she has less time to care for the children and tends to more equally share childrearing responsibilities with the father - which is then more likely to be continued as a shared care arrangement after separation (Meyer et al. 2017; Poortman and van Gaalen 2017). Conversely, mother sole custody is more likely when the mother stayed home (more often than the father) to take care of the children (Cancian et al. 2014). Meanwhile, it remains unclear to what extent changes in labor force participation after separation affect the likelihood of parents opting for shared physical custody later on, and whether this differs for mothers and fathers. On the one hand, it is true that many mothers who want to return to the workforce or increase their work volume after separation encounter challenges such as insufficient qualifications or inadequate childcare coverage, trapping them in unemployment or part-time jobs. On the other hand, if a mother were to successfully increase her work volume after the break-up, the new organization of her life may simply be better suited with a shared physical custody arrangement than with sole custody (Meyer et al. 2017). For fathers, we expect different mechanisms to be at play. In this respect it is important to 
note that greater fatherly involvement in childcare has not led to a notable decrease in Belgian fathers' labor force participation. Also, mothers are still in a stronger position to receive custody (Nielsen 2013a; Sodermans et al. 2011), and having enough resources to care for a child remains a more important consideration for granting custody to fathers than to mothers (Nielsen 2011). This could be especially relevant in the still strongly male-breadwinner oriented Belgian context, where fathers continue to be considered primarily as providers. As such, insofar a father is not yet in full-time employment, it could be expected that a post-separation increase in his work volume may also be of importance in switching to shared physical custody. We therefore formulate the following hypotheses:

Hla: An increase in the mother's work volume after separation increases the likelihood that the ex-partners switch to shared physical custody 2 years after separation.

H1b: An increase in the father's work volume after separation increases the likelihood that the ex-partners switch to shared physical custody 2 years after separation.

It then remains to be seen to what extent the "continuity of care" principle, i.e. that custody outcomes are reflective of the pre-separation care roles (Juby et al. 2005), remains dominant in predicting whether or not parents share care. When investigating the abovementioned hypotheses, we will therefore control for the relative labor force participation of parents - reflecting the division of childcare - prior to separation.

\subsubsection{Parental Financial Position}

Another important predictor of shared physical custody after separation is the joint parental income. Accommodating a child in each parent's, rather than a joint, household increases the total living and transportation expenses for that child. A shared physical custody arrangement is therefore simply more feasible for couples with more resources (Juby et al. 2005; Kalmijn 2015; Melli and Brown 1994). However, the parental financial situation is not a "fixed" characteristic; job loss, promotion, etc. after separation can induce major shifts in both the joint and relative income position of parents. As having enough resources is an important prerequisite of raising a child in two homes, it seems plausible that an increase in the joint parental income after separation increases the likelihood of switching to shared care later on. The second aspect, relative income, is more complex. Parents' relative financial position is an indicator of bargaining power, and as such also of importance in predicting the custody arrangement (Natalier and Hewitt 2010). When considering the pre- or at-separation household, having shared physical custody is more common among couples who contributed relatively equally to the household finances (Bartfeld 2011). Conversely, and due to mothers still holding a stronger position in gaining custody, a mother's financial advantage over the father makes it more 
likely to end up with a sole custody arrangement (Cancian and Meyer 1998; Nielsen 2013a). It could therefore be expected that mothers who experience significant financial gains after separation also increase their bargaining power to obtain sole custody, thus making the switch to shared physical custody less likely. Considering the importance of fathers' resources in obtaining custody, a father's financial gains after separation would increase the likelihood of him gaining custody and thus sharing care with his ex-partner. This translates into the following hypotheses:

H2a: An increase in the joint parental income after separation increases the likelihood that the ex-partners switch to shared physical custody 2 years after separation.

$H 2 b$ : An increase in the mother's income after separation decreases the likelihood that the ex-partners switch to shared physical custody 2 years after separation. H2c: An increase in the father's income after separation increases the likelihood that the ex-partners switch to shared physical custody 2 years after separation.

We will again control for the joint and relative contribution to the household finances prior to separation in order to consider their lasting importance vis à vis post-separation dynamics.

\subsubsection{Re-partnering}

The third post-separation change we consider is the parents' partner status. As starting a new family affects parents' available time, having responsibilities towards a new partner and children ${ }^{1}$ can increase the benefits of having shared, rather than sole, custody (Cancian et al. 2014). This is especially true for mothers, for whom most studies conclude that the time restrictions and conflicting commitments introduced by having a new partner significantly increase the likelihood of her sharing care, rather than having sole custody (Cancian and Meyer 1998; Juby et al. 2005; Maccoby and Mnookin 1992). The reverse is true for fathers, who tend to experience a decrease in the likelihood of having shared physical custody when entering a new partnership (Cooksey and Craig 1998; Kelly 2007; Smyth 2005). Still, the underlying mechanisms are essentially the same for men and women. As the pattern concerns mothers moving from more mother-oriented arrangements to shared care and fathers from shared care to less frequent visitation, the result of re-partnering is a reduction in custody of children (Bakker and Mulder 2013).

It is important to note, however, that the results for fathers are more ambiguous than for mothers, with certain studies finding no effect at all of men's re-partnering on sharing care (Juby et al. 2005; Smyth and Weston 2004). Furthermore, just as with other characteristics, a parent tends to be considered as "being re-partnered" at

\footnotetext{
${ }^{1}$ In this chapter we only consider the impact of re-partnering and not of having new children, as we only follow parents up to 2 years after the separation.
} 
the time of separation or the study. It is therefore difficult to put forward causal suggestions concerning the effect of re-partnering on having shared physical custody later on. In a recent longitudinal study on the stability of shared physical custody, Poortman and van Gaalen (2017) found that if a father re-partners after separation, changing from shared to mother sole residence is more likely than staying in shared custody. This is in line with the abovementioned studies and the finding that a new partner decreases the frequency of contact with children for fathers (Bakker and Mulder 2013). Meanwhile, mother's re-partnering was found to have no effect on the stability of the shared care arrangement. A potential explanation is that, when comparing shared and sole custody, mothers who already had shared custody are already at the "minimum" time spent with their children. The time restrictions induced by the new partner may nevertheless still have affected the initial choice for shared custody (Cancian et al. 2014). As such, concerning the likelihood of switching to shared physical custody 2 years after separation, we expect to find similar results for re-partnering as to what has previously been found. We therefore formulate the following hypotheses:

H3a: Mother's re-partnering increases the likelihood that the ex-partners switch to shared physical custody 2 years after separation.

H3b: Father's re-partnering decreases the likelihood that the ex-partners switch to shared physical custody 2 years after separation.

\subsubsection{Household and Demographic Characteristics}

Not only the socio-economic position and time restraints of parents are important when considering the likelihood of sharing care after separation. Previous research has found that several other socio-demographic and household characteristics are in play. First of all, the age of the child tends to be of great importance. Shared physical custody is less likely for very young children, as infants benefit more from stability in physical care. For older children who have a say in custody proceedings, alternating residences is also found to be less common (Cancian and Meyer 1998; Juby et al. 2005; Sodermans et al. 2013a). Shared custody arrangements have been found to be more likely for boys than for girls, as - from the perspective of increased father involvement when sharing care - fathers generally invest more care in sons than daughters (Spruijt and Duindam 2010). Due to the more extensive care requirements in large families, parents with a greater number of children more frequently opt for a shared custody arrangement (Kalmijn and De Graaf 2000). Finally, while previous research did not find a relationship between the union type and the likelihood of having shared physical custody (Juby et al. 2005; Poortman and van Gaalen 2017), we expect to find some differences in our analyses. As explained in Sect. 2.1, we study a specific Belgian form of fiscal shared physical custody. Choosing for this constellation requires some knowledge of its fiscal implications and insight in the workings of tax returns. Previously married and legally cohabiting parents, for 
whom tax returns are joint and more complex (Swennen and Mortelmans 2015), could therefore be more likely to opt for fiscal shared physical custody than parents who were informally cohabiting. The age of the youngest child, the gender(s) and number of children and the previous union type of the ex-partners will be included as control variables in the analyses.

As we use administrative records, we cannot account for several important variables related to sharing care. Some examples are parents' education (Cancian et al. 2014), the distance between parents' homes (Bakker and Mulder 2013), mediation and level of conflict between parents (Sodermans et al. 2013a), (mental) health problems (Poortman and van Gaalen 2017) and father's involvement in childcare (Juby et al. 2005). While changes in labor force participation and relationship status could be interacting with some of these factors, we cannot consider them as proxies. Nevertheless, this does not undermine the useful potential of our data in casting a longitudinal lens on the determinants of having shared physical custody.

\subsection{Data and Method}

\subsubsection{Register Data}

We make use of register data comprised of information on income, labor and sociodemographics from the Belgian Crossroads Bank for Social Security, linked to fiscal information from individual tax returns. The original sample consists of couples who experienced a divorce or separation either in 2008 or 2011 and were not married or cohabiting 1 year afterwards. The dataset commences 1 year prior to separation and follows each parent, along with their consecutive household(s), up to 2013. We pooled both groups (separated in 2008 or 2011) and selected only those respondents who had at least one minor child 2 years after separation (i.e. in 2010 or 2013). This is an important requirement, as until 2016 fiscal shared physical custody was only possible for children under the age of 18 . Because we cannot know to which child the arrangement pertains, we reduce the risk of wrongly attributing it to other children than joint children by omitting couples where one or both parents already have a fiscal shared physical custody, pay child support or have children other than joint children in the household. Same-sex couples are excluded in order to assess gender differences, along with ex-partners who re-partnered with each other within 2 years of separating. Leaving out couples where a partner has missing data on any of the used variables (see Table 7.1), gives us a final subsample of 10,171 couples who were not sharing care after separation, of which 1039 adopted fiscal shared physical custody 2 years after separation. 
Table 7.1 Descriptive statistics of categorical predictors and controls

\begin{tabular}{|c|c|c|}
\hline \multicolumn{2}{|l|}{ Variables } & $\%$ \\
\hline \multirow[t]{2}{*}{ Separation year } & 2008 & $48 \%$ \\
\hline & 2011 & $52 \%$ \\
\hline \multirow[t]{2}{*}{ Child gender $($ ref $=$ mixed $)$} & All boys & $36 \%$ \\
\hline & All girls & $34 \%$ \\
\hline \multirow[t]{2}{*}{ Number of children $(\mathrm{ref}=1)$} & 2 & $42 \%$ \\
\hline & $\geq 3$ & $12 \%$ \\
\hline \multirow[t]{2}{*}{ Previous union (ref $=$ married $)$} & Legally cohab. & $9 \%$ \\
\hline & Informally cohab. & $38 \%$ \\
\hline \multirow{2}{*}{ Relative income (ref $=$ mother $<$ father) } & Mother $=$ father & $27 \%$ \\
\hline & Mother > father & $24 \%$ \\
\hline \multirow[t]{2}{*}{ Relative work volume $(\mathrm{ref}=$ mother $<$ father) } & Mother $=$ father & $26 \%$ \\
\hline & Mother $>$ father & $18 \%$ \\
\hline \multirow[t]{3}{*}{ Re-partnering (ref $=$ neither) } & Only mother & $13 \%$ \\
\hline & Only father & $14 \%$ \\
\hline & Both & $4 \%$ \\
\hline
\end{tabular}

$N=10,171$

\subsubsection{Measures}

The dependent variable in the analysis is switching to fiscal shared physical custody 2 years after separation. The required information was found in each parent's tax return. Three conditions had to be met in order for us to consider the parents to be sharing custody: one of the ex-partners indicated to be doing so and have the children living with them, the other partner indicated to be doing so while the children were domiciled with the other partner and both parents registered the same number of children for whom the arrangement was in place. As the dependent variable in the logistic regression models, fiscal shared physical custody received a binary $0 / 1$ coding, with 1 representing having switched to the arrangement 2 years after separation (i.e. 2010 or 2013). The reference category consists of all parents who did not switch to the arrangement. Regrettably, we do not have information on any other custody arrangements and thus lump together families where the mother has sole custody, the father has sole custody, parents have unequal shared care etc. This can undeniably bias our results, as we are ignoring that previous custody agreements may affect whether or not parents move into shared physical custody (i.e. it may be easier going from unequal to equal shared physical custody than from sole custody). However, this issue does not effectively hinder our research in the sense that our goal is to investigate which parental and household characteristics motivate a switch to fiscal shared physical custody, rather than look at differences between care regimes. This is nevertheless a limitation that should be taken into account and addressed by further research.

The main focus of the analyses is on how post-separation dynamics of parents' post-separation labor force participation, income and partner status affect the likelihood of switching to shared physical custody. Nevertheless, as children's living 
arrangements are initially decided upon during separation, it is important to also account for the pre-separation household (Juby et al. 2005). We therefore firstly consider the total pre-separation joint income of parents and the relative income situation 1 year prior to separation, where a partner contributed either less than $45 \%$, more than $55 \%$ or relatively equally (i.e. $45-55 \%$ ) to the total income (coded as dummy variables). To assess the effect of post-separation financial shifts on switching to shared physical custody, we calculate an absolute indicator of change in income for both the joint income and each ex-partner's individual income 1 year after separation versus the pre-separation situation. Next we consider work volume, expressed as the total number of full days worked in a year divided by the number of workdays in that year. This provides an indicator of yearly work volume ranging from 0 (unemployed) to 1 (regular full-time work) for each parent. These are added up to obtain the pre-separation joint work volume of parents, ranging from 0 (both parents unemployed) to 2 (both parents in regular full-time employment). For the pre-separation relative labor market participation, we used the same ratio as for income to distinguish between situations where a partner's yearly work volume prior to the separation was smaller, larger or a relatively equal to that of the other partner. Dynamics in labor force participation are calculated as an absolute indicator of change in the work volume for each parent 1 year after separation versus the pre-separation situation. We also distinguish between both parents re-partnering after separation versus only the mother, only the father or neither parent (dummy coding).

Further, we control for the age of the youngest child and whether parents were either legally or informally cohabiting or married prior to separating (coded as dummy variables). Also included are post-separation control variables, lagged by 1 year to explore causal effects on the likelihood of switching to shared physical custody. We consider the number of joint minor children (eligible for fiscal shared physical custody) and whether these children were all boys, all girls or mixed (dummy coding) 1 year prior to (not) switching to shared physical custody (i.e. 1 year after separation). To take into account the possibility that fiscal shared care was becoming more established, we also control for the year of separation (2008 or 2011). The descriptive statistics of all variables used in the analysis are presented in Table 7.1 (see infra).

\subsubsection{Method}

Using SAS 9.4, logistic regression models were applied to the longitudinal register data to test the likelihood that parents switch to shared physical custody 2 years after separation (Table 7.3). First, we estimate a model containing only the fixed pre-, atand post-separation variables to control for the (lasting) importance of these characteristics in sharing care (Model 1). We then add the longitudinal indicators of change to the model (Model 2). This allows us to determine the effect of post-separation shifts on the likelihood of switching to shared physical custody vis à vis the lasting dominance of pre-separation characteristics. 
Table 7.2 Descriptive statistics and bivariate correlations of continuous predictors and controls

\begin{tabular}{|c|c|c|c|c|c|}
\hline \multicolumn{2}{|l|}{ Variable } & Mean & SD & Q1 & Q3 \\
\hline \multicolumn{2}{|l|}{ Age youngest child } & 5 & 4 & 2 & 7 \\
\hline \multicolumn{2}{|l|}{ Joint income (gross, €) } & 57,771 & 27,285 & 40,160 & 70,300 \\
\hline \multicolumn{2}{|c|}{ Joint work volume $(\max =2)$} & 1.058 & 0.583 & 0.663 & 1.496 \\
\hline \multicolumn{2}{|c|}{ Change income mother (gross, $€$ ) } & 5759 & 8863 & 2050 & 9740 \\
\hline \multicolumn{2}{|c|}{ Change income father (gross, €) } & 2336 & 11,271 & -740 & 5910 \\
\hline \multicolumn{2}{|c|}{ Change $\mathrm{WV}^{\mathrm{a}}$ mother $(\max =1)$} & 0.03 & 0.275 & -0.01 & 0.09 \\
\hline \multicolumn{2}{|c|}{ Change $\mathrm{WV}^{\mathrm{a}}$ father $(\max =1)$} & -0.04 & 0.282 & -0.08 & 0.01 \\
\hline \multicolumn{6}{|c|}{\begin{tabular}{|l|l} 
Bivariate correlations & \\
\end{tabular}} \\
\hline 1 & 2 & 3 & 4 & 5 & 6 \\
\hline \multicolumn{6}{|l|}{1} \\
\hline$-0.184 * *$ & 1 & & & & \\
\hline$-0.131 * *$ & $-0.060 * *$ & 1 & & & \\
\hline$-0.036^{* *}$ & $-0.051 * *$ & $-0.140 * *$ & 1 & & \\
\hline$-0.034 * *$ & $-0.018 * *$ & $-0.033 * *$ & $-0.045 * *$ & 1 & \\
\hline$-0.030 * *$ & $-0.001 * *$ & $-0.165^{* *}$ & $-0.441 * *$ & $0.020 * *$ & 1 \\
\hline$-0.011 * *$ & $-0.051 * *$ & $-0.194 * *$ & $-0.007 * *$ & $0.479 * *$ & 0.014 \\
\hline
\end{tabular}

$N=10,171$

$* p<0.05 ; * * p<0.01$

${ }^{\mathrm{a}} W V$ work volume

As we make use of register data, missing data due to non-response or attrition does not pose the same issues as in survey-based longitudinal research (Wallgren and Wallgren 2007). Nevertheless, the integration of several registers into a complete dataset does imply missing information. In our dataset, a missing on a specific variable generally means that someone is not registered with the recording instance. Where we lack information on income or work volume, we are dealing with people who are not part of the regular employee system (e.g. self-employed). As this group makes use of a separate tax return form (which we do not have access to), about $2 \%$ of our original sample has largely missing values. On the one hand, this group potentially experiences different post-separation dynamics concerning income and work volume than the rest of the sample. On the other hand, as the fiscal system of shared physical custody may have a significantly different impact on this group, it may be prudent to study them separately anyway. Considering these arguments, and as the sample size remains sufficiently large without these cases, we opt to omit this group completely.

\subsection{Results}

\subsubsection{Descriptive Results}

Table 7.1 shows the frequencies of the categorical predictors and control variables included in the analysis. Next, Table 7.2 presents the descriptive statistics of the 
Table 7.3 Logistic regression models with pre- at- and post-separation predictors

\begin{tabular}{|c|c|c|c|c|}
\hline & \multicolumn{2}{|l|}{ Model 1} & \multicolumn{2}{|l|}{ Model 2} \\
\hline & \multicolumn{2}{|c|}{ Pre-separation/fixed } & \multicolumn{2}{|c|}{ Post-separation/change } \\
\hline & $\operatorname{Exp}(b)$ & Sig. & $\operatorname{Exp}(b)$ & Sig. \\
\hline Age youngest child at separation & 1.151 & $* *$ & 1.156 & $* *$ \\
\hline Age youngest child squared & 0.988 & $* * *$ & 0.988 & $* * *$ \\
\hline \multicolumn{5}{|l|}{ Child gender $($ ref $=$ mixed $)$} \\
\hline All children boys & 1.169 & & 1.176 & \\
\hline All children girls & 1.195 & & 1.194 & \\
\hline \multicolumn{5}{|l|}{ No. of minor children $($ ref $=1)$} \\
\hline 2 & 1.125 & & 1.108 & \\
\hline$\geq 3$ & 1.286 & $*$ & 1.305 & $*$ \\
\hline \multicolumn{5}{|l|}{ Prev. union $($ ref $=$ married $)$} \\
\hline Legally cohabiting & 0.739 & $*$ & 0.723 & $* *$ \\
\hline Informally cohabiting & 0.543 & $* * *$ & 0.550 & $* * *$ \\
\hline Joint income (€10.000) & 1.464 & $* * *$ & 1.445 & $* * *$ \\
\hline Joint income squared & 0.988 & $* * *$ & 0.988 & $* *$ \\
\hline \multicolumn{5}{|l|}{ Relative income $^{a}$} \\
\hline Mother $=$ father & 1.471 & $* * *$ & 1.485 & $* * *$ \\
\hline Mother $>$ father & 1.259 & $*$ & 1.248 & $*$ \\
\hline Joint work volume & 1.236 & $*$ & 1.398 & $* * *$ \\
\hline \multicolumn{5}{|l|}{ Relative work volume ${ }^{a}$} \\
\hline Mother $=$ father & 0.972 & & 0.998 & \\
\hline Mother $>$ father & 0.999 & & 0.987 & \\
\hline Separation in 2011 (vs. 2008) & 1.169 & $*$ & 1.149 & $*$ \\
\hline Change income mother & & & 1.044 & \\
\hline Change income mother squared & & & 1.002 & \\
\hline Change income father & & & 1.040 & \\
\hline Change income father squared & & & 1.003 & \\
\hline Change work volume mother & & & 1.585 & $* *$ \\
\hline Change work volume mother squared & & & 1.129 & \\
\hline Change work volume father & & & 1.831 & $* *$ \\
\hline Change work volume father squared & & & 0.952 & \\
\hline \multicolumn{5}{|l|}{ Re-partnering $($ ref $=$ none $)$} \\
\hline Both re-partnered & & & 1.076 & \\
\hline Only mother & & & 1.434 & $* *$ \\
\hline Only father & & & 0.842 & \\
\hline$-2 \mathrm{LL}$ & 6181.925 & & 6113.893 & \\
\hline AIC & 6219.925 & & 6173.893 & \\
\hline
\end{tabular}

$N=10,171$

$* p<.050 ; * * p<.010 ; * * * p<.001$

${ }^{\mathrm{a}}$ Ref $=$ mother $<$ father 
continuous predictors and controls, along with their bivariate correlations. The highest correlations are, not unexpectedly, found between the change of income and change in work volume, both for mothers $(r=0.44 ; p<0.01)$ as for fathers $(r=0.48 ; p<0.01)$.

\subsubsection{Multivariate Results}

Table 7.3 presents the results of the logistic regression models predicting the likelihood of switching to shared physical custody 2 years after separation. Model 1 contains the odds for the pre-separation and fixed controls, while Model 2 adds the effect of post-separation changes in parents' work volume, income and partner status. Overall, pre- and at-separation socio-demographic, economic and household factors remain dominant predictors of sharing care, even 2 years after separation. As expected, the age of the youngest child is non-linear in effect. The likelihood of switching to shared physical custody first increases steeply, peaks at the age of 4 and then consistently decreases again. Next, we find that ex-partners have a higher likelihood of switching to shared care if they have more minor children eligible for the fiscal shared physical custody arrangement, no matter the gender of the children. The previous union of parents also has an effect, though slightly different than expected. Not only informally, but also legally cohabiting significantly reduces the likelihood of switching to shared physical custody, compared to previously having been married. Furthermore, there is no significant difference between the effect of legally and informally cohabiting on switching to shared physical custody.

Model 1 also confirms the importance of joint and relative income for the likelihood of sharing care after separation. First, it is a more likely option for parents who have more resources. However, this effect is non-linear, with a steep initial increase ending in a subtle decrease for the higher-income groups. Second, gender equality is also in play: a relatively equal contribution of mother and father to the joint finances increases the likelihood of switching to a shared physical custody arrangement after separation. Interestingly, this is also the case when mothers earn more than fathers.

While it could be expected that a higher financial capacity places mothers in a stronger bargaining position to gain sole custody, we may very well be seeing a (societally induced) shift towards a personal preference for shared, rather than sole, custody. Furthermore, greater resources are significantly correlated with a higher labor force participation ( $r=0.52, p<.001)$, making it more likely (1) that the father took up a significant share of childcare during the relationship and (2) that the mother experiences time restraints that make sharing custody after separation more suitable to her. This may explain why we find no significant effect of parents' relative labor force participation on the likelihood of switching to shared physical custody in Model 1. Finally, the odds of opting for shared physical custody 2 years after separation is greater for who separated in 2011 rather than in 2008, which may again reflect the societal shift towards sharing care. 
These results remain quasi unchanged when adding post-separation life course and labor force dynamics to the model (Model 2), which confirms the continuing effect of the pre- and at- separation household, parent and child characteristics on sharing care after separation. A notable difference is the effect of the total pre-separation parental work volume, which is highly significant when including the post-separation dynamics in Model 2. Parents who had a higher work volume prior to separation, are more likely to switch to shared physical custody 2 years afterwards. However, there is no significant difference in the likelihood of sharing care between couples where mothers had an equal or higher, versus lower work volume than fathers. Moving on, Model 2 tests whether post-separation changes in income, labor force participation and partner status affect the likelihood switching to shared physical custody, over and above the pre- and at-separation characteristics. We test for the effect of increases in income by separately adding the change in total joint and individual income to the model. Only individual income changes are included in Model 2, as - against our expectations - an increase in the total joint income after separation did not affect the likelihood of sharing care. In other words, contrary to the pre-separation income, increasing the pooled resources later on does not further encourage parents to switch to shared physical custody. This also holds true for the change in individual income. While the mother's equal or greater contribution to the joint finances during the relationship increases the likelihood of sharing care, neither an increase in her nor the father's income after separation affects switching to a shared physical custody arrangement. Interestingly, labor force participation shows opposite results. In Model 1, work volume (and thus implicit time restraints) of parents had little effect on switching to shared physical custody. Conversely, in Model 2, both the total work volume of parents before separation and an increase in individual work volume after separation significantly increase the likelihood of sharing care. The odds are greater for fathers, supporting the claim that being employed is still a more important consideration for fathers than it is for mothers when deciding on the custody arrangement. An interaction was tested between the effect of mother's and father's change in work volume on opting for shared physical custody, but the result was not significant. Finally, Model 2 considers the effects of mother's and father's re-partnering. As expected, if a mother re-partners, the likelihood of switching to shared physical custody is higher than when both partners remain single. However, this is dependent on father's partner status: if both parents re-partner, the likelihood of sharing care does not differ from when both parents are still single.

\subsection{Discussion}

Following the societal evolution towards more equality in parenting and household responsibilities, shared physical custody is increasingly becoming the postseparation parenting norm in Western society (DiFonzo 2014). This trend is supported by the increasing body of research stating that post-separation care by 
both parents is not only beneficial for children, but for parents as well (Van der Heijden et al. 2015; Westphal 2015). Furthermore, while generally not legally imposing it, many countries support shared physical custody by adapting their legal frameworks (Nielsen 2011; Nikolina 2012; Perelli-Harris and Gassen 2012) or by considering it in the calculation of child support (Claessens and Mortelmans 2018; Skinner and Davidson 2009). As a result, shared physical custody after separation has become more common practice and the families choosing this arrangement less distinctive (Meyer et al. 2017), allowing for a wider implementation (of the benefits) of equality in care roles for separated parents. Research nevertheless shows that couples who already experienced more socio-economic, work- and childcare-related equality during their relationship are more likely to share care and that different factors still facilitate and inhibit mothers and fathers to enter a shared physical custody arrangement. However, existing studies are often limited to cross-sectional data, considering only the pre- or at-separation household with respect to the likelihood of sharing care at the time of separation or the study. As such, it remains unclear how the inevitable re-organization in parents' lives after separation affects equality in custody arrangements. Controlling for important pre-separation characteristics, this chapter investigates the influence of three postseparation dynamics (financial position, labour force participation and re-partnering) on switching to an equally shared physical custody arrangement 2 years after separation. Furthermore, we investigate whether post-separation changes that facilitate or inhibit equal caretaking differ for mothers and fathers.

Studies with recent data show that, due to the more general adoption of shared physical custody among a broad variety of families, child, parent and household characteristics have become less predictive of sharing care (Bartfeld 2011). Our results do not entirely support this. First, we do find confirmation that shared physical custody is less likely for very young and for older children (Juby et al. 2005; Maccoby and Mnookin 1992). However, while recent studies found no association with family size (Cancian et al. 2014; Sodermans et al. 2013a), our results do concur with earlier studies showing a positive relationship between a couple's number of eligible children and their likelihood of sharing care (Kalmijn and De Graaf 2000). This could nevertheless be due to the small (10\%) number of families with three or more children eligible for fiscal shared physical custody in our sample. Further, the fiscal implications of this arrangement led us to presume that it would be more likely to be chosen by previously married or legally cohabiting couples. However, our results show that previously cohabiting, both legally and informally, reduces the likelihood of switching to fiscal shared physical custody compared to previously married couples. While earlier research explained this relationship as married fathers being more committed to family life and more likely to maintain contact with children than cohabiting fathers (Marcil-Gratton et al. 2000), the increasing acceptance of cohabiting as a suitable parenting union has done away with this disparity (Juby et al. 2005; Swiss and Le Bourdais 2009). As such, we expect that the fiscal shared physical custody arrangement is more likely for married couples in our sample not due to the nature of the union, but due to the still more pervasive legal and fiscal framework surrounding marriage in Belgium (FOD Financiën 2018b). 
Although there is evidence that the financial advantage of parents with shared physical custody over parents with a sole custody arrangement is becoming less pervasive (Cancian et al. 2014; Sodermans et al. 2011), we find that the likelihood of sharing care still increases with income. As Melli and Brown (1994) point out, a higher income not only adds to the feasibility of raising a child in two households, but is also positively related to gender equal attitudes on the division of work and childcare, which higher-earning parents can more easily maintain after separation. For the highest income group however, we see a decline in the likelihood of sharing care. An excessive income may point to a more-than-regular work schedule, potentially giving this group less time for childcare and thus leading to a reduced likelihood of switching to shared physical custody. As an indicator of gender equality, a more equal contribution of parents to the joint resources prior to separation increases the likelihood of sharing care later on (Bartfeld 2011). Unexpectedly, this likelihood is also higher in families with higher-earning mothers, while previous research suggests that a mother who contributes more to the total income has more power to influence the custody decision and receive sole custody (Cancian and Meyer 1998). We consider two explanations. On the one hand, our findings support the hypothesis that being in paid employment makes mothers more open to sharing custody (Juby et al. 2005). On the other hand, the societal and normative shift towards sharing care may encourage parents to use their financial "power" to obtain this more (socially) desirable arrangement. This may also explain why the relative work volume during the relationship does not affect the likelihood of switching to shared physical custody in our analysis: no matter the division of labor between couples, it is now expected that both mother and father take up care of the children. If this is true, a better predictor would be the actual contribution to childcare by each parent during the relationship, as this encourages both parents' continued involvement after separation (Poortman and van Gaalen 2017). Unfortunately, we lack information on actual involvement in childrearing. Nevertheless, in the final model we see that the total joint work volume of parents positively affects switching to shared physical custody. Insofar a greater work volume implies greater time restraints for childcare, this finding provide some support for the continuity of care principle (Juby et al. 2005).

Next, we consider the importance of post-separation changes in parents' income, work volume and partner status vis-à-vis the pre- and at-separation situation. In terms of having enough resources to raise a child in two homes, the bargaining power of parents and being in paid work, it could be expected that an increase in mother's, father's and/or the joint parental income increases the likelihood that parents switch to shared physical custody. However, this does not appear to be the case. A possible explanation is that Belgian parents may not be as inclined to reveal increases in their income after separation, as equally sharing care does not exempt parents from having to pay child support if the other partner is in a financially weaker position (Claessens and Mortelmans 2018, in press). As such, the gained bargaining power due to the income increase could be counterbalanced with a potential renegotiation of custody and child support payments, because fiscal shared physical 
custody cannot be combined with the payment of child support ${ }^{2}$ (FOD Financiën 2018a). Conversely, we find that both an increase of mother's and father's work volume increases the likelihood of switching to shared physical custody 2 years after separation. Considering the recent shift from mother sole custody to shared physical custody as the parenting norm and default judicial preference, we suggest the effect of mother's increased labor participation to reflect more experienced time restraints, making sharing care with an ex-partner more preferable than sole custody. For fathers to receive custody, being in paid work and able to provide for the child is still of greater importance than it is for mothers (Nielsen 2013a; Sodermans et al. 2011). Therefore, we are not surprised to find that when a father increases his work volume after separation, parents are more likely to switch to shared physical custody.

The final post-separation change we considered was re-partnering. Existing research provides mixed findings concerning the relationship between having a new partner and shared physical custody, especially for fathers. Furthermore, studies often face the issue of not being able to pinpoint a clear causal relationship (Juby et al. 2005; Kalmijn and De Graaf 2000; Poortman and van Gaalen 2017). Our results show that if a mother re-partners soon after separation, the ex-partners are more likely to switch to shared care. Furthermore, while not refuting that the custody arrangement can influence a parent's decision to re-partner (Bakker and Mulder 2013), the longitudinal nature of our data allows us to posit that a new partner creates time restraints for mothers, making shared physical custody more interesting for her. For fathers, re-partnering does not have a significant effect. This is may be because fathers do not experience significantly less time for a social life when sharing care than when having visitation rights (Bakker and Karsten 2013), suggesting that re-partnering may be perceived as less of a time constraint. However, we find that if both parents are re-partnered, the likelihood of switching to shared physical custody is not significantly different from when neither parent is in a new relationship. This could indicate that the positive effect of mother's re-partnering is neutralized by that of father's re-partnering, meaning that father's re-partnering does to some extent - have, as hypothesized, a negative effect on the likelihood of switching to shared care. Nevertheless, this relatively unexplored causal relationship between re-partnering and shared physical custody merits further investigation.

\subsubsection{Limitations}

Despite the usefulness of our longitudinal data, some limitations can be noted. As previously stated, we cannot account for some potentially important variables related to shared physical custody. It would therefore be useful to supplement our administrative data with survey data to obtain more social and subjective measures. We

\footnotetext{
${ }^{2}$ Child support payments cannot be deducted from taxes when having fiscal shared physical custody.
} 
would also benefit from a variable that more accurately reflects time in paid work than our current yearly work volume indicator, for which a score of 0.5 can either indicate working half-time for an entire year or full-time for half a year. A precise measure of time spent in paid work and working hours on a weekly basis would be an undeniably better proxy of time spent with children. Our study of relatively recent separations (2008 and 2011) also limits the amount of time after separation we could consider for both groups. Furthermore, we undeniably miss an important group that shares care outside of the fiscal constellation, which may be a financial consideration. As Vanassche et al. (2017) explain, not opting for fiscal shared physical custody may be a strategic choice of the parent with whom the child is officially domiciled to not share generous child-related benefits and allowances with the other parent. This could imply that parents who have a fiscal shared physical custody arrangement are more prepared to share benefits and are less conflicted. However, as non-fiscal care sharing allows for the payment of child support, the unbalance in received child benefits could easily be corrected. Furthermore, our results match findings where shared physical custody is not a fiscal constellation. As such, we have reason to assume that parents who have fiscal shared physical custody are representative of parents who share care in Belgium at large.

Meanwhile, our data has distinct advantages. First, administrative records provide detailed information over time, with minimal risk of attrition. Furthermore, we have official data on the parenting arrangement and are thus not reliant on parents' own reports, which may be incorrect due to generalizations or recall bias (Sodermans et al. 2014). Of course, we are not certain that if a tax return indicates fiscal shared physical custody this corresponds with parents equally dividing the care of the child. However, this potential discrepancy is an issue faced by all child support research (Juby et al. 2005). Furthermore, it seems unlikely that in the case of fiscal shared physical custody the reality would vary strongly from an equal time share. If one parent did not take up as much care as the other, that last parent could easily claim child support to compensate for the unequal burden of the childcare costs, especially as the non-cooperative parent is claiming half of the child-related tax benefits. Not having to pay (more) child support can therefore be an incentive to respect the equal shared physical custody arrangement. Second, by considering the fiscal arrangement, we are provided with a definition of equally sharing care. This precisely delimited time share shelters our interpretations from difficulties faced by other studies. For example, when defining shared physical custody as "spending at least 33 percent of time with each parent", children who live one-third with their father and two-thirds with their mother are lumped together with children who equally live with both parents, while it is to be expected that these time shares have different implications for e.g. the quality of the parent-child relationship, re-partnering opportunities and the financial burden on parents (Claessens and Mortelmans 2018; Vanassche et al. 2017).

Finally, in terms of adapting to the changing needs of the ever-growing group of separated and complex families, Belgium's fiscal shared physical custody is somewhat of a forerunner. As Meyer et al. (2017) point out, many countries' tax and benefit policies are dependent on family size and/or the number of children in the 
household, which, due to the increase in shared physical custody, can vary on a regular basis (Hakovirta and Rantalaiho 2011). This highlights the need to reexamine how families are defined in policy and allow for more flexible arrangements between separated parents. In this respect, fiscal shared physical custody sets a good example.

\subsection{Conclusions}

By looking into the effects of the pre- and at-separation household versus postseparation life course and labor force dynamics on sharing care, this chapter aims to increase the existing knowledge on what facilitates and inhibits an equal division of childcare after separation. Overall, while the analysis shows that certain characteristics remain predictive of sharing care, we also see the impact of the societal trend towards equal shared physical custody as the parenting norm in Belgium. Although bargaining power in terms of income and pre-separation division of work are generally seen as arguments for mothers to obtain sole custody, our results suggest that they no longer significantly work against sharing care with the father. Moreover, the discovered post-separation effects may be an indication of parents supporting and encouraging gender equal parenting, by not using income increases to claim more custody and by reacting to increases in labor force participation by choosing for shared physical custody. Considering the benefits of sharing childcare in terms of gender equality, parental well-being and the parent-child relationship (Van der Heijden et al. 2015; Westphal 2015), further research is warranted into how the post-separation dynamics in lives of parents can affect the likelihood of sharing care. Taking into account the reorganization of parents' lives and potential variability in children's residence during the early years after separation (Poortman and van Gaalen 2017), we suggest to consider a more prolonged post-separation period to further our understanding of not only how parents' custody needs and preferences change after separation, but also which factors (continue to) facilitate gender equal parenting for mothers and fathers.

Acknowledgement This chapter benefited from the support of the Centre for Population, Family and Health (CPFH) at the University of Antwerp which enabled Open Access.

\section{References}

Bakker, W., \& Karsten, L. (2013). Balancing paid work, care and leisure in post-separation households: A comparison of single parents with co-parents. Acta Sociologica, 56(2), 173-187.

Bakker, W., \& Mulder, C. H. (2013). Characteristics of post-separation families in the Netherlands: Shared residence versus resident mother arrangements. GeoJournal, 78(5), 851-866. 
Bartfeld, J. (2011). Shared placement: An overview of prevalence, trends, economic implications, and impacts on child well-being. Report, Institute for Research on Poverty, University of Wisconsin-Madison.

Bauserman, R. (2002). Child adjustment in joint-custody versus sole-custody arrangements: A meta-analytic review. Journal of Family Psychology, 16(1), 91.

Bianchi, S. M., Sayer, L. C., Milkie, M. A., \& Robinson, J. P. (2012). Housework: Who did, does or will do it, and how much does it matter? Social Forces, 91(1), 55-63.

Cancian, M., \& Meyer, D. R. (1998). Who gets custody? Demography, 35(2), 147-157.

Cancian, M., Meyer, D. R., Brown, P. R., \& Cook, S. T. (2014). Who gets custody now? Dramatic changes in children's living arrangements after divorce. Demography, 51(4), 1381-1396.

Claessens, E., \& Mortelmans, D. (2018). Challenges for child support schemes: Accounting for shared care and complex families. Journal of European Social Policy, 28(3), 211-223.

Claessens, E., \& Mortelmans, D. (2018, in press). De toegankelijkheid, werkbaarheid en transparantie van de Belgische methoden ter berekening van onderhoudsbijdragen voor kinderen. Belgisch Tijdschrift voor Sociale Zekerheid.

Cooksey, E. C., \& Craig, P. H. (1998). Parenting from a distance: The effects of paternal characteristics on contact between nonresidential fathers and their children. Demography, 35(2), 187-200.

de Regt, S., Mortelmans, D., \& Marynissen, T. (2012). Financial consequences of relationship dissolution: A longitudinal comparison of formerly married and unmarried cohabiting men and women. Sociology, 47(1), 90-108.

DiFonzo, J. H. (2014). From the rule of one to shared parenting: Custody presumptions in law and policy. Family Court Review, 52(2), 213-239.

Fehlberg, B., Smyth, B., Maclean, M., \& Roberts, C. (2011). Legislating for shared time parenting after separation: A research review. International Journal of Law, Policy and the Family, 25(3), 318-337.

Feinberg, M. E., Kan, M. L., \& Hetherington, E. M. (2007). The longitudinal influence of coparenting conflict on parental negativity and adolescent maladjustment. Journal of Marriage and Family, 69(3), 687-702.

FOD Financiën. (2018a). Co-ouderschap en fiscaliteit. Retrieved from https://financien.belgium.be/ $\mathrm{nl} /$ particulieren/gezin/gezinssituatie/co-ouderschap

FOD Financiën. (2018b). Gezinssituatie. Retrieved from https://financien.belgium.be/nl/ particulieren/gezin/gezinssituatie

FOD Financiën. (2018c). Kinderen ten laste.. Retrieved from https://financien.belgium.be/nl/ particulieren/gezin/personen_ten_laste/kinderen

Gezinsbond. (2021). Kies bewust voor fiscaal co-ouderschap, want dit is niet altijd de beste optie. Fiscaal Co-ouderschap, https://www.gezinsbond.be/Gezinspolitiek/ onderhoudsgeldcalculator/Paginas/Fiscaal-co_ouderschap.aspx.

Hakovirta, M., \& Rantalaiho, M. (2011). Family policy and shared parenting in Nordic countries. European Journal of Social Security, 13, 247.

Juby, H., Le Bourdais, C., \& Marcil-Gratton, N. (2005). Sharing roles, sharing custody? Couples' characteristics and children's living arrangements at separation. Journal of Marriage and Family, 67(1), 157-172.

Kalmijn, M. (2015). Father-child relations after divorce in four European countries: Patterns and determinants. Comparative Population Studies, 40(3), 251-276.

Kalmijn, M., \& De Graaf, P. (2000). Gescheiden vaders en hun kinderen: een empirische analyse van voogdij en bezoekfrequentie. Bevolking en Gezin, 29(2), 59-84.

Kelly, J. B. (2007). Children's living arrangements following separation and divorce: Insights from empirical and clinical research. Family Process, 46(1), 35-52.

Maccoby, E. E., \& Mnookin, R. H. (1992). Dividing the child: Social and legal dilemmas of custody. Cambridge, MA: Harvard University Press.

Maldonado, S. (2014). Shared parenting and never-married families. Family Court Review, 52(4), 632-638. 
Marcil-Gratton, N., Le Bourdais, C., \& Lapierre-Adamcyk, É. (2000). The implications of parents' conjugal histories for children. Ottawa: Department of Justice, Research and Statistics Division.

Melli, M., \& Brown, P. (1994). The economics of shared custody: Developing an equitable formula for dual residence. Houston Law Review, 31, 543.

Meyer, D. R., Cancian, M., \& Cook, S. T. (2017). The growth in shared custody in the United States: Patterns and implications. Family Court Review, 55(4), 500-512.

Mortelmans, D., Pasteels, I., Bracke, P., Matthijs, K., Van Bavel, J., \& Van Peer, C. (2011). Scheiding in Vlaanderen. Leuven: Acco.

Natalier, K., \& Hewitt, B. (2010). 'It's not just about the money': Non-resident fathers' perspectives on paying child support. Sociology, 44(3), 489-505. https://doi.org/10.1177/ 0038038510362470 .

Nielsen, L. (2011). Shared parenting after divorce: A review of shared residential parenting research. Journal of Divorce \& Remarriage, 52(8), 586-609. https://doi.org/10.1080/ 10502556.2011.619913.

Nielsen, L. (2013a). Shared residential custody: Review of the research (part I of II). American Journal of Family Law, 27(1), 61-71.

Nielsen, L. (2013b). Shared residential custody: Review of the research (part II of II). American Journal of Family Law, 27, 123-137.

Nielsen, L. (2014). Shared physical custody: Summary of 40 studies on outcomes for children. Journal of Divorce \& Remarriage, 55(8), 613-635.

Nikolina, N. (2012). The influence of international law on the issue of co-parenting-emerging trends in international and European instruments. Utrecht Law Review, 8, 122.

Perelli-Harris, B., \& Gassen, N. S. (2012). How similar are cohabitation and marriage? Legal approaches to cohabitation across Western Europe. Population and Development Review, 38(3), 435-467.

Poortman, A. R., \& van Gaalen, R. (2017). Shared residence after separation: A review and new findings from the Netherlands. Family Court Review, 55(4), 531-544.

Skinner, C., \& Davidson, J. (2009). Recent trends in child maintenance schemes in 14 countries. International Journal of Law, Policy and the Family, 23(1), 25-52.

Smyth, B. M. (2005). Time to rethink time? The experience of time with children after divorce. Family Matters, 71, 4.

Smyth, B. M., \& Weston, R. (2004). The attitudes of separated mothers and fathers to 50/50 shared care. Family Matters, 67, 8.

Sodermans, A. K., Vanassche, S., \& Matthijs, K. (2011). Gedeelde kinderen en plusouders: de verblijfsregeling en de gezinssituatie na scheiding. In D. Mortelmans, I. Pasteels, J. Pacolet, P. Bracke, K. Matthijs, J. Van Bavel, \& C. Van Peer (Eds.), Scheiding in Vlaanderen. Leuven/ Den Haag: Acco.

Sodermans, A. K., Matthijs, K., \& Swicegood, G. (2013a). Characteristics of joint physical custody families in Flanders. Demographic Research, 28(29), 821-848.

Sodermans, A. K., Vanassche, S., \& Matthijs, K. (2013b). Verblijfsregelingen en welbevinden van kinderen: Verschillen naar gezinskenmerken. Relaties en Nieuwe Gezinnen, 3(11), 1-29.

Sodermans, A. K., Vanassche, S., Matthijs, K., \& Swicegood, G. (2014). Measuring postdivorce living arrangements: Theoretical and empirical validation of the residential calendar. Journal of Family Issues, 35(1), 125-145.

Spruijt, E., \& Duindam, V. (2010). Joint physical custody in the Netherlands and the well-being of children. Journal of Divorce \& Remarriage, 51(1), 65-82.

Swennen, F., \& Mortelmans, D. (2015). National report: Belgium. In K. Boele-Woelki (Ed.), European Family Law in Action: Informal Relationships. Intersentia.

Swiss, L., \& Le Bourdais, C. (2009). Father-Child contact after separation: The influence of living arrangements. Journal of Family Issues, 30(5), 623-652.

Thielemans, G., \& Mortelmans, D. (2019). Female labour force participation after divorce: How employment histories matter. Journal of Family and Economic Issues, 40(2), 180-193. 
Trinder, L. (2010). Shared residence: A review of recent research evidence. Child and Family Law Quarterly, 22, 475.

Van der Heijden, F., Gähler, M., \& Härkönen, J. (2015). Are parents with shared residence happier? Children's Postdivorce residence arrangements and parents' life satisfaction. Stockholm Research Reports in Demography, 17, 1-35.

Van Krieken, R. (2005). The 'best interests of the child' and parental separation: On the 'civilizing of parents. The Modern Law Review, 68(1), 25-48.

Vanassche, S., Sodermans, A. K., Declerck, C., \& Matthijs, K. (2017). Alternating residence for children after parental separation: Recent findings from Belgium. Family Court Review, 55(4), 545-555.

Wallgren, A., \& Wallgren, B. (2007). Register-based statistics: Administrative data for statistical purposes (Vol. 553). Chichester: Wiley.

Westphal, S. K. (2015). Are the kids alright? Essays on postdivorce residence arrangements and children's well-being. Utrecht: Utrecht University.

Elke Claessens is a post-doc researcher in Sociology within the Centre for Population, Family and Health (CPFH) and a teaching assistant in the Faculty of Political and Social Sciences at the University of Antwerp (Belgium). She teaches Applied Multivariate Statistics to master students in Sociology and Socio-Economical sciences, as well as Research Methods to the third bachelor students of the Faculty of Political and Social Sciences. Her research mainly focusses on the determination and objectification of child support, both in a national and international setting. More recently, her work also includes the investigation of shared physical custody patterns in Belgium.

Dimitri Mortelmans is Full Professor of Sociology at the Faculty of Political and Social Sciences of the University of Antwerp, Belgium. He is head of the Centre for Population, Family, and Health $(\mathrm{CPFH})$. His research concentrates on family sociology and sociology of labour. He has published on divorce, new constituted families, gendered labour careers and work-life balance. He is also the main author of the Step in Statistics book series of which six volumes have been published (in Dutch). On qualitative methodology, he published the Handbook of Qualitative Research Methods and Qualitative Analysis with NVivo. In demography, he (co-)edited Changing Family Dynamics and Demographic Evolution. The Family Kaleidoscope (Edward Elgar), Lone parenthood in the Life Course (Springer) and Divorce in Europe (Springer).

Open Access This chapter is licensed under the terms of the Creative Commons Attribution 4.0 International License (http://creativecommons.org/licenses/by/4.0/), which permits use, sharing, adaptation, distribution and reproduction in any medium or format, as long as you give appropriate credit to the original author(s) and the source, provide a link to the Creative Commons license and indicate if changes were made.

The images or other third party material in this chapter are included in the chapter's Creative Commons license, unless indicated otherwise in a credit line to the material. If material is not included in the chapter's Creative Commons license and your intended use is not permitted by statutory regulation or exceeds the permitted use, you will need to obtain permission directly from the copyright holder.

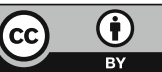

